\title{
PROFESI PENGAMEN DALAM PERSPEKTIF HUKUM EKONOMI SYARIAH
}

\author{
M.S. Almujaddedi \\ Institut Agama Islam Negeri Batusangkar \\ Email: almujaddedi181295@gmail.com \\ Zainuddin \\ Institut Agama Islam Negeri Batusangkar \\ Email: zainuddin@iainbatusangkar.ac.id
}

\begin{abstract}
Abstrak
Islam mencela segala bentuk meminta-minta untuk memenuhi kebutuhan dan sebaliknya Islam menganjurkan agar dapat bekerja dengan tangan sendiri atau melalui hasil keringat sendiri bukan mengharap balas kasihan dari orang lain. Profesi pengamen merupakan salah satu bentuk fenomena yang terjadi di tengah masyarakat dimana pengamen tersebut memiliki prilaku yang berbedabeda dalam memperoleh keuntungan yaitu dengan cara gelandangan dan dengan cara tidak gelandangan sehingga terdapat perbedaan dalam menetapkan hukum profesi pengamen dalam tinjauan hukum ekonomi syariah.
\end{abstract}

\section{Kata Kunci : Pengamen, Hukum Ekonomi Syariah}

\begin{abstract}
Islam denounces all forms of begging to meet needs and vise versa Islam advocates that it can work with one's own hands or through the result of one's own sweat rather than expecting pity from other. The busker profesion is one of the phenomena that occur in the community where the buskers have different behaviors in obtaining profits, namely by wy of homeless people and by wy of non-homeles people so that there are differences in establishing the law of buskers in the review of Islamic economic Law.
\end{abstract}

Keywords: Buskers, sharia economic law. 


\section{A. PENDAHULUAN}

Pada zaman globalisasi, masyarakat dituntut untuk lebih mempunyai skill dan kemampuan teknik agar mampu bersaing di dunia kerja. Selain itu tuntutan untuk menempuh pendidikan yang lebih tinggi merupakan suatu hal yang tidak dapat dipisahkan sebagai persiapan persaingan di dunia kerja. Tuntutan untuk bisa memenuhi kebutuhannya menyebabkan masyarakat harus bisa bersaing terutama dalam mengelola potensinya (Pratama, 2017). Namun, bagi yang mempunyai keterbatasan serta adanya dorongan untuk memenuhi kebutuhan dengan segera menyebabkan mereka harus memenuhi kebutuhannya dengan cara apapun termasuk menjadi pengamen yang menjadi topik dalam pembahasan ini.

Menurut Kamus Besar Bahasa Indonesia yang dimaksud dengan pengamen adalah suatu kegiatan menyanyi di jalanan yang dilakukan oleh individu atau kelompok baik dengan memakai alat musik atau tidak serta meminta upah yang dianggap sebagai jasa atas hiburan yang telah diberikan (Depertemen Pendidikan dan Kebudayaan, 2017). Dari pengertian tersebut menurut Suharto (2011) pengamen melakukan kegiatannya dengan cara bernyanyi dan dilakukan di jalanan atau fasilitas umum yang terdapat di sepanjang jalan seperti rumah makan, tempat wisata, perjalanan darat menumpang di atas mobil, lampu merah, dan dari rumah ke rumah. Semakin hari semakin banyak pengamen yang menghabiskan waktunya untuk bekerja di jalanan dan tempat-tempat umum seperti lampu merah, angkutan umum, pasar, mall, taman kota dan sebagainya. Padahal jalanan merupakan tempat yang sangat berbahaya bagi mereka (Suharto, 2011).

Dalam Undang Undang Nomor 31 Tahun 1980 tentang Penanggulangan Gelandangan dan Pengemis mengatakan bahwa gelandangan dan pengemis tidak sesuai dengan norma kehidupan bangsa Indonesia yang berdasarkan Pancasila dan Undang-Undang Dasar 1945. Adapun ciri-ciri gelandangan menurut Peraturan Daerah Kota Makasar Nomor 2 Tahun 2008 adalah berpindah-pindah sampai mendapatkan sedikit uang dalam tempo yang cepat, berharap balas kasihan dari orang lain, tidak mempunyai kreatifitas melainkan hanya memaksimalkan apa yang dimiliki, serta bukan niat untuk menghibur. Pengamen jenis ini juga berprilaku premanisme. Baju yang compang camping, adanya unsur memaksa 
pemberian upah, premanisme, tidak mempunyai kreatifitas, dan alat musik yang digunakan sangat sederhana (seperti tutup botol, seng bekas) atau bahkan tidak memiliki alat musik sekalipun (hanya dengan tepuk tangan saja). Pendapatan cenderung dari hasil meminta-minta atau mengemis. Profesi pengamen seperti ini dikelompokkan dalam jenis pengamen gelandangan. Contohnya adalah para gembel (gelandangan) dan banci (Nugroho, Sularto, dan Wicaksono, 2017).

Rasulullah SAW memberikan contoh kepada umat Islam bahwasanya bekerja merupakan sebuah keharusan agar manusia dapat memenuhi kebutuhannya. Rasulullah SAW merupakan pedagang ulung dan sukses sehingga menjadi kaya. Berkat kekayaannya beliau mampu memberi mahar kepada Siti Khadijah sebesar 20 ekor unta muda sebagai mahar dan 12,5 uqiyah (ons) emas. Kesuksesan tersebut tidak terlepas dari ketekunan dan kejujuran beliau dalam berwirausaha. Beliau tidak mau bekerja dari hasil meminta-minta apalagi dengan mengharap balas kasihan dari orang lain (al-Misri, 2008). Bahkan Rasulullah SAW melaknat orang-orang yang bekerja dengan cara meminta-minta atau mengharap balas kasihan dari orang lain. Hal ini disebutkan dalam dua hadis Rasulullah SAW yaitu :

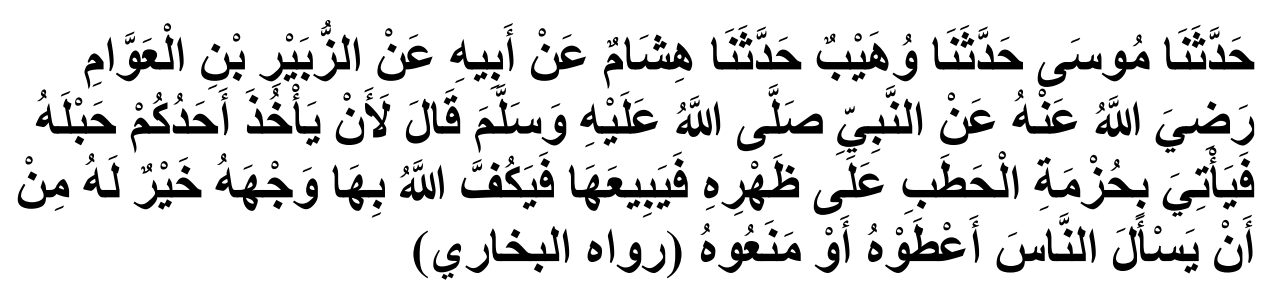

"Telah menceritakan kepada kami [Musa] telah menceritakan kepada kami [Wuhaib] telah menceritakan kepada kami [Hisyam] dari [bapaknya] dari [Az Zubair bin Al 'Awam radliallahu 'anhu] dari Nabi Shallallahu'alaihiwasallam bersabda: "Demi Dzat yang jiwaku berada di tanganNya, sungguh seorang dari kalian yang mengambil talinya lalu dia mencari seikat kayu bakar dan dibawa dengan punggungnya kemudian dia menjualnya lalu Allah mencukupkannya dengan kayu itu lebih baik baginya daripada dia meminta-minta kepada manusia, baik manusia itu memberinya atau menolaknya" (H.R. Buhkari). 
Selain dengan cara meminta-minta, profesi pengamen juga dilakukan dengan niat murni untuk menghibur, tidak menggelandang dari suatu tempat ke tampat lain, berada di suatu titik, memakai alat, dilakukan secara berkelompok dan kreatif seperti yang terjadi pada kelompok pengamen di berbagai kota di Indonesia seperti grup angklung di Yogyakarta (Putra dan Susetyo, 2012), grup dendang badarak di Sumatera Barat (Fulzi, 2016), dan grup angklung sunda di Bandung, Jawa Barat (Masunah, 2015). Dalam mencari keuntungan mereka hanya menempatkan suatu kotak dan tidak pernah berkeliling. Menurut Saraswati (2018) pengamen di Kota Yogyakarta sebagai kota wisata budaya untuk berkreasi memilih lagu dan alat musik yang sesuai dengan budaya orang jawa. Contohnya adalah grup angklung yang bertugas menghibur wisatawan di lesehan malioboro. Selain itu ada juga yang berbentuk grup musik seperti grup musik yang menamakan dirinya sebagai grup musisi jogja project. Ada juga pengamen yang berkeliling di pasar malioboro menggunakan mikrofon dan file musik instrument menggunakan speaker yang di sandang (Saraswati, 2018). Contoh lain adalah grup dendang badarak yang diberitakan oleh harianhaluan.com dimana grup ini menyewa kafe-kafe yang ada di Kota Padang untuk menghibur pengunjung kafe dengan musik tradisionalnya (Fulzi, 2016). Contoh lain adalah grup angklung di berbagai kota di Jawa Barat yang datang ke tempat-tempat wisata dengan mngurus perizinan mengamen dari kepolisian untuk melakukan kegiatannya (Masunah, 2015). Jika dibandingkan dengan Peraturan Daerah (Perda) Provinsi Daerah Istimewa Yogyakarta Nomor 1 Tahun 2014 tantang Penanganan Gelandangan dan Pengemis yang menyebutkan bahwa pengamen yang tidak dibenarkan dan akan ditertibkan oleh pemerintah DIY adalah pengamen yang berprofesi sebagai gelandangan dan melakukan usahanya dengan mengemis, maka berbagai cara mengamen yang dilakukan secara professional di berbagai Kota di Indonesia tidak berprofesi dengan gelandangan.

Dari berbagai literatur yang ditemukan belum ditemukan penelitian yang membahas tentang hukum profesi pengamen dalam tinjauan hukum ekonomi syariah. Walian (2012) berpendapat bahwa Islam tidak menyukai kepada penganggur, pengemis dan pribadi yang menggantungkan kebutuhan diri dan keluarganya pada orang lain. Penelitian Fahlepy (2018) 
menjelaskan bahwa dilihat dari ketentuan hukum positif kegiatan meminta atau mengemis dikategorikan sebagai perbuatan pelanggaran terutama bagi daerah yang memiliki perda sehingga sanksi yang diberikan dapat berupa pidana maupun sanksi administrasi. Pernyataan tersebut didukung oleh penelitian Tarmudzi (2015) bahwasanya Undang-undang membedakan antara kejahatan atau pelanggaran mengingat berat ringannya hukuman, sedangkan hukum pidana Islam tidak membedakannya, semuanya disebut jarîmah mengingat sifat pidananya. Sementara Wardi (2012) berpendapat bahwa permintaan yang dilakukan di jalan raya bisa mendatangkan madlarah, seperti perilaku mengemis yang dilarang dalam Islam,

Seluruh literatur yang telah dikemukakan tersebut hanya membahas hukum meminta-minta dan sementara penelitian ini membahas tentang hukum profesi pengamen dimana pengamen dalam melakukan kegiatannya juga terdapat unsur mengemis dan meminta-minta serta mengharap balas kasihan dari orang lain. Masalah utama dalam makalah ini adalah adanya perbedaan karakteristik mengamen. Menurut Putra (2019) terdapat dua karakteristik profesi pengamen. Pertama profesi pengamen yang memperoleh keuntungan dengan cara meminta-minta dan mengharap balas kasihan dari orang lain. Tidak ada unsur profesionalitas dalam profesi ini. Kedua pengamen yang memperoleh keuntungan dengan berusaha untuk menghindari cara meminta-minta. Oleh sebab itu keunikan cara ini mengakibatkan penetapan hukum mengamen berbeda-beda yang ditinjau dari hukum ekonomi syariah sehingga menimbulkan pertanyaan penelitian yaitu "Bagaimana tinjauan hukum Islam terhadap profesi pengamen?"

\section{B. METODE}

Penelitian ini merupakan penelitian library research (penelitian kepustakaan). Penelitian library research adalah penelitian yang dilakukan bukan ditempat obyek penelitian berada melainkan dilakukan di dalam ruangan dengan mengumpulkan sumber-sumber data melalui dokumentasi (Sugiyono, 2014). Pengumpulan data dalam peneilitian ini dilakukan dengan cara mengumpulkan seluruh dokumen-dokumen yang relevan dengan penelitian melalui media elektronik, peraturan daerah dan perundang-undangan, serta literatur yang relevan mengenai profesi pengamen dalam tinjauan hukum ekonomi syariah. Data diolah dan 
dianalisis menggunakan analisis konten (content analysis) secara deskriptif kualitatif.

\section{PEMBAHASAN}

Rasulullah SAW memberikan contoh kepada umat Islam bahwasanya bekerja merupakan sebuah keharusan agar manusia dapat memenuhi kebutuhannya. Beliau tidak mau bekerja dari hasil memintaminta apalagi dengan mengharap balas kasihan dari orang lain. Bahkan Rasulullah SAW melaknat orang-orang yang bekerja dengan cara memintaminta atau mengharap balas kasihan dari orang lain. Oleh sebab itu Islam memerintahkan umat Islam untuk bekerja dan berusaha. Allah SWT berfirman dalam Q.S. At-Taubah ayat 105 :

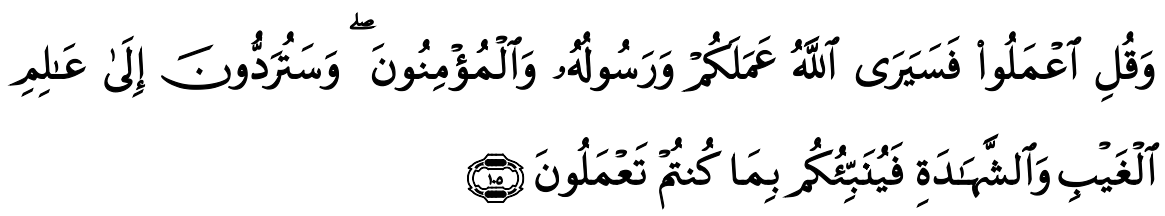

"Dan Katakanlah: "Bekerjalah kamu, Maka Allah dan Rasul-Nya serta orang-orang mukmin akan melihat pekerjaanmu itu, dan kamu akan dikembalikan kepada (Allah) yang mengetahui akan yang ghaib dan yang nyata, lalu diberitakan-Nya kepada kamu apa yang telah kamu kerjakan”. (Q.S. At-Taubah ayat 105)

Bekerja merupakan salah satu bentuk untuk mencari harta dan merupakan bagian dari kegiatan muamalah. Hukum awal seluruh kegiatan muamalah adalah mubah seperti yang disebutkan dalam fiqh muamalah

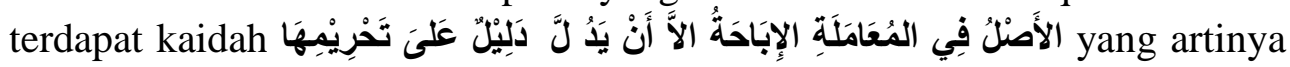
adalah "hukum asal dari muamalah adalah boleh sampai terdapat dalil yang mengharamkannya". Dalam kaidah ini dapat diartikan sebagai hukum asal dari seluruh transaksi muamalah adalah boleh sampai ada dalil yang mengharamkannya (Djazuli, 2006). Adapun tujuan bermuamalah adalah mewujudkan mewujudkan kebaikan dan kesejahteraan (mashlahah) umat manusia di dunia dan akhirat. Untuk mencapai tujuan ini ada lima unsur pokok yang harus dipelihara yang dinamakan mashlahuh khamsah yang terdiri dari agama, jiwa akal, keturunan, dan harta (Nurhayati dan Wasilah, 2015). 
Dalam Islam terdapat dua istilah yang mengatur tentang pemberian upah terhadap sesuatu yang ia terima dari hasil kerja orang lain yaitu ji'alah dan ujrah. Jialah artinya sesuatu yang diberikan kepada seseorang atas sesuatu yang telah ia kerjakan (Iska, 2017). Sedangkan menurut Sayyid Sabiq (1983) ji'alah adalah sebuah akad untuk mendapatkan materi (upah) yang diduga kuat dapat diperoleh. Istilah ji'alah dalam kehidupan seharihari diartikan sebagai memberi upah kepada orang lain atas kepada orang lain atas setiap pekerjaan yang dapat memberikan manfaat kepada seseorang. Sedengkan ujrah diberikan oleh seseorang atas suatu sewa yang diberikan oleh pemilik sewa (Iska, 2017). Menurut Ath-Thayar (2017) ji'alah adalah transaksi yang tidak mengikat berbeda dengan ijarah yang merupakan transaksi mengikat. Artinya dalam ji'alah pekerja atau pemberi pekerjaan berhak untuk membatalkan transaksi, selain itu dalam ji'alah pekerjaan tidak ditentukan sebelumnya oleh kedua belah pihak sedangkan ujrah dalam ijarah merupakan suatu transaksi yang mengikat antara pemberi sewa dengan penerima sewa baik sewa barang ('ain) atau jasa ( $a d z$ dzimah) (Iska, 2017).

Dalam mengamen, para pengamen tidak mengikatkan dirinya kepada pendengar nyanyiannya (Yendika, 2011) artinya disini tidak terjadi akad yang mengikat antara pengamen dan pendengar. Profesi pengamen juga tidak terdapat ikatan akad sebelumnya. Pengamen datang kepada pendengar tanpa diikuti ijab qabul antara kedua belah pihak (Uli, 2012). Selain itu para pengamen tidak menentukan besaran upah atas nyanyiannya atau menyerahkan kepada pendengar apakah ingin membayar upah atau tidak kepada pengamen (Munawwaroh, 2009). Oleh sebab itu, transaksi yang terjadi dalam profesi pengamen ini lebih tepatnya adalah akad ji'alah.

Para ulama fukaha sepakat hukum ji'alah adalah mubah atau boleh (Ghozaly, dkk, 2012). Adapun landasan hukum dari ji'alah adalah Q.S. Yusuf ayat 72 :

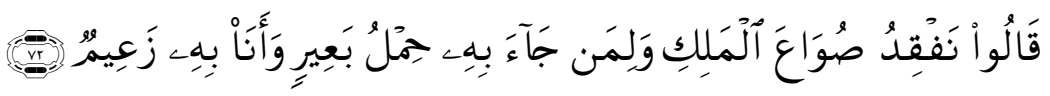


"Penyeru-penyeru itu berkata: "Kami kehilangan piala Raja, dan siapa yang dapat mengembalikannya akan memperoleh bahan makanan (seberat) beban unta, dan aku menjamin terhadapnya".

Adapun rukun dari ji'alah adalah antara lain : a) aqida'in, b) shighah, c) pekerjaan, dan d) upah. Akad ji'alah dapat dibatalkan. Jika pembatalan ji'alah datang dari orang yang bekerja maka ia tidak mendapatkan upah namun jika pembatalan datang dari orang yang memberi pekerjaan maka yang bekerja berhak menuntut upahnya sesuai dengan kesepakatan (Ath-Thayar, 2017). Dalam teori ekonomi, upah secara umum di maknai sebagai harga yang dibayarkan kepada pekerja atas jasanya dalam produksi kekayaan seperti faktor produksi lainnya, tenaga kerja diberikan imbalan atas jasanya yang disebut upah. Sementara Sadono Soekirno mendefinisikan upah sebagai pembayaran yang diperoleh atas berbagai bentuk jasa yang disediakan dan diberikan oleh tenaga kerja kepada para pengusaha (Iska dan Rizal, 2005).

Profesi pengamen merupakan salah satu bentuk fenomena yang terjadi di tengah masyarakat dimana pengamen tersebut memiliki prilaku yang berbeda-beda dalam memperoleh keuntungan yaitu dengan cara gelandangan dan dengan cara tidak gelandangan (Putra, 2019) sehingga terdapat perbedaan dalam menetapkan hukum profesi pengamen dalam tinjauan hukum ekonomi syariah. Menurut Putra (2019) terdapat dua macam bentuk penghasilan pengamen yaitu dengan meminta-minta dan dengan tidak meminta-minta. Penghasilan pengamen yang dilakukan dengan cara meminta-minta identik dengan pengamen gelandangan. Sedangkan profesi pengamen yang dilakukan menjahi unsur meminta-minta dilakukan dengan cara tidak gelandangan. Oleh sebab itu menurut peneliti pembagian jenis pengamen dapat dibagi menjadi berikut (Putra, 2019) :

\section{Pengamen Gelandangan}

Pengamen gelandangan adalah pengamen yang melakukan usahanya dengan cara berkeliling dan pendapatan yang dihasilkannya bersumber dari harapan balas kasihan dari orang yang dituju. Ciri-ciri pengamen gelandangan adalah berpindah-pindah sampai mendapatkan sedikit uang dalam tempo yang cepat, berharap balas kasihan dari orang lain, tidak mempunyai kreatifitas melainkan hanya memaksimalkan apa 
yang dimiliki, serta bukan niat untuk menghibur. Pengamen jenis ini juga berprilaku premanisme. Premanisme adalah kegiatan sekelompok orang yang mendapatkan penghasilannya terutama dari pemerasan sekelompok masyarakat lain yang bersifat seperti orang yang suka memeras dan melakukan kejahatan (Nugroho, Sularto, dan Wisaksono, 2017). Terdapat dua jenis pengamen gelandangan dalam fenomena ini yaitu (Putra, 2019) :

a. Tidak Ada Unsur Usaha

Pengamen jenis ini murni sebagai pengemis dengan ciri-ciri baju yang compang camping, adanya unsur memaksa pemberian upah, premanisme, tidak mempunyai kreatifitas, dan alat musik yang digunakan sangat sederhana (seperti tutup botol, seng bekas) atau bahkan tidak memiliki alat musik sekalipun (hanya dengan tepuk tangan saja). Pendapatan cenderung dari hasil meminta-minta atau mengemis. Contohnya adalah para gembel (gelandangan) dan banci (Putra, 2019).

b. Ada Unsur Usaha

Pengamen jenis ini memiliki sedikit perbedaan dengan pengamen jenis pertama dimana pengamen ini berusaha untuk memberikan layanan kepada para pendengarnya. Pada jenis pengamen ini mereka sudah menggunakan alat musik seperti gitar, microfon, dan speaker serta telah berusaha mengeluarkan seluruh potensi suara yang dimilikinya namun masih memenuhi syarat dari pengertian gelandangan dari PERDA DIY Nomor 1 Tahun 2014. Meskipun sudah terdapat unsur usaha namun pengamen jenis ini masih dimasukkan dalam kategori pengamen gelandangan karena sering berpindah tempat dalam tempo yang singkat dan adanya unsur mengemis (Putra, 2019). Contohnya adalah para pengamen jalanan yang menggunakan gitar dan berpindah-pindah dari suatu tempat ke tampat lain, pengamen buta yang menyanyi di sepanjang pasar malioboro memiliki nyanyian yang bagus, dan pengamen yang hanya duduk sambil bermain musik dan meminta-minta sambil 
mengatakan "tolong kasihan saya mas, mbak" padahal fisiknya masih mampu untuk bekerja lebih dari itu.

Menurut PERDA DIY Nomor 1 tahun 2014, karakteristik gelandangan dan pengemis adalah sebagai berikut :

a. Gelandangan adalah orang-orang dengan kriteria antara lain :

1) Tanpa Kartu Tanda Penduduk (KTP)

2) Tanpa tempat tinggal yang pasti/tetap;

3) Tanpa Penghasilan yang tetap, dan/atau

4) Tanpa rencana hari depan anak-anaknya maupun dirinya

b. Pengemis adalah orang-orang dengan kriteria antara lain :

1) Mata pencahriannya tergantung pada belas kasihan orang lain

2) Berpakaian kumuh, compang camping, dan tidak sewajarnya

3) Berada ditempat-tempat umum

4) Memperalat sesama untuk merangsang belas kasihan orang lain

Dalam Islam mengemis atau meminta-minta dinamakan dengan Tawasul. Menurut Rafi, Hamzah, dan Rafif (2017) Awalnya, tidak ada pelarangan dalam meminta-minta, bahkan, Islam pun tidak melarangnya secara mutlak. Namun, ketika fenomena mengemis tujuannya bukan lagi untuk mencari tambahan hidup, melainkan lebih kepada profesi, hal itu menyebabkan banyak daerah di Indonesia memberlakukan larangan meminta-minta di jalan serta larangan memberi uang kepada pengemis sehingga meminta-minta sangat dicela dalam Islam. Fahlepy (2018) menguraikan hukum meminta-minta sebagai berikut :

a. Jika meminta-minta dilakukan oleh orang yang sangat terdesak tersebut hukumnya boleh

b. Jika meminta-minta itu dilakukan sebagai profesi (pekerjaan) maka hukumya haram

c. Jika meminta-minta itu dilakukan bukan kebiasaan hukumnya makruh

Pekerjaan yang bersumber dari cara meminta-minta bahkan dengan cara gelandangan tidak hanya dicela di dalam Islam namun juga dilarang dalam Peraturan Indonesia. Hal ini disebabkan karena profesi yang dijalankan dengan cara tersebut akan berdampak pada tatanan 
perkotaan yang semrawut dan mengganggu ketertiban umum. Dalam pasal 504 KUHP disebutkan bahwa : (1) Barangsiapa mengemis di muka umum, diancam karena melakukan pengemisan dengan pidana kurungan paling lama enam minggu dan (2) Pengemisan yang dilakukan bersamasama oleh tiga orang atau lebih, yang masing masing berumur di atas enam belas tahun, diancam dengan pidana kurungan paling lama tiga bulan. Dalam Pasal 505 disebutkan bahwa : (1) Barangsiapa bergelandangan tanpa mempunyai mata pencaharian, diancam karena melakukan pergelandangan dengan pidana kurungan paling lama tiga bulan dan (2) Pergelandangan yang dilakukan bersamasama oleh tiga orang atau lebih, yang masing-masing berumur di atas enam belas tahun, diancam dengan pidana kurungan paling lama enam bulan (Kartono, 2018)

Dari penjelasan diatas dapat disimpulkan bahwa hukum pengamen yang menjalankan profesinya dengan mengemis hukumnya haram. Profesi pengamen yang menjalankan ushanya dengan cara meminta-minta sangat dicela di dalam Islam sehingga hukumnya haram. Adapun dalil yang mengharamkannya adalah Hadis Nabi Muhammad SAW yang berbunyi :

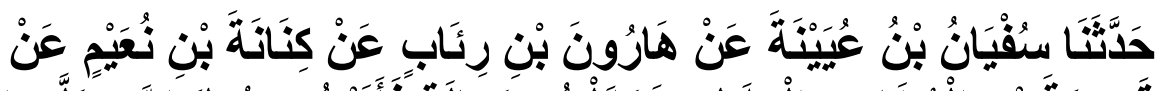

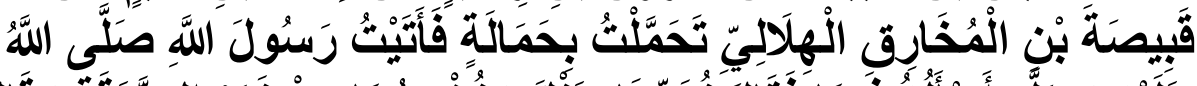

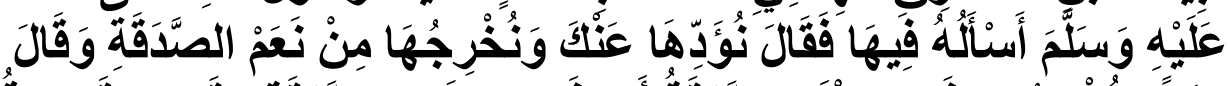

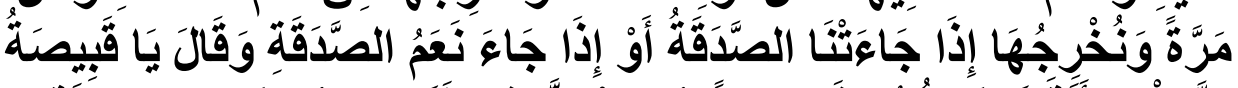

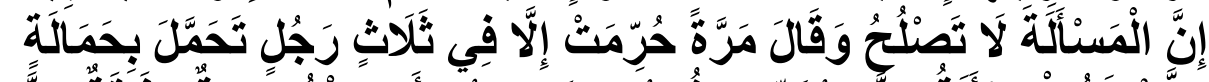

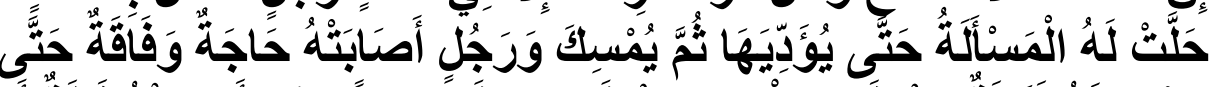

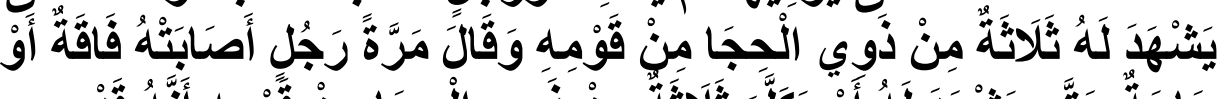

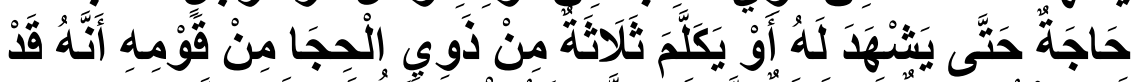

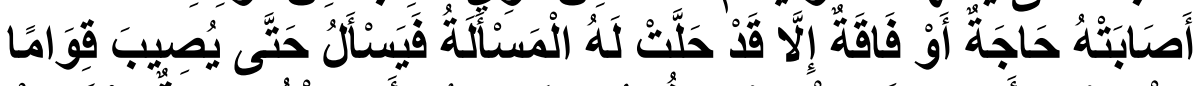

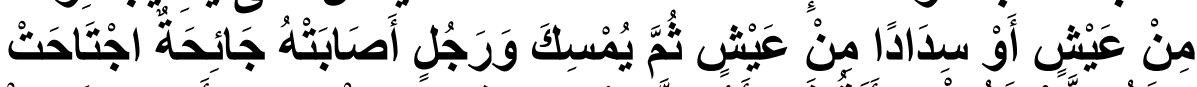

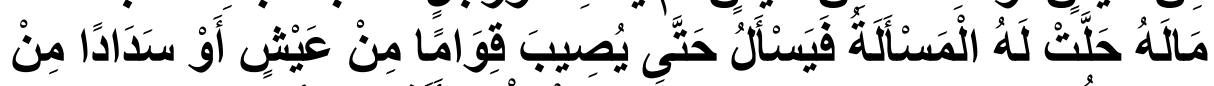

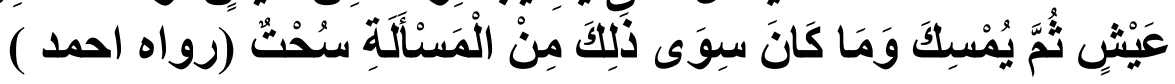


"Telah menceritakan kepada kami [Sufyan bin 'Uyainah] dari [Harun bin Ri'ab] dari [Kinanah bin Nuaim] dari [Qabishah bin Muhariq Al Hilali] saya mempunyai banyak tanggungan, lalu saya mendatangi Rasulullah Shallallahu'alahiwasallam dan meminta bantuan, Lalu beliau bersabda: "Kami akan menyelesaikan tanggunganmu dan mengambilkan dari ternak-ternak sedekah" Pada lain kesempatan, bersabda: "Kami akan membantumu jika sedekah telah datang atau jika kita mendapatkan ternak-ternak sedekah". Lalu beliau bersabda: "Wahai Qabishah, meminta-minta itu tidak boleh, --dalam lain kesempatan dengan redaksi diharamkan-- kecuali dalam tiga kondisi, yaitu kondisi seseorang karena mempunyai tanggungan maka diperbolehkan untuk meminta-minta sampai dia mampu untuk menyelesaikan tanggungannya lantas berhenti. Seseorang yang sedang terdesak karena kebutuhan dan kefakiran hingga disaksikan oleh tiga orang dari kaumnya yang berakal, --dalam kesempatan lain dengan redaksi 'Seseorang yang sedang terdesak karena kefakiran dan kebutuhan hingga tiga orang berakal dari kaumnya bersaksi atau mengucapkan ucapan bahwa ia terdesak kebutuhan atau kefakiran, sehingga meminta dihalalkan baginya, lalu dia meminta hingga memperoleh penopang hidup atau kecukupan hidupnya lantas ia menahan diri, dan ketiga, seseorang yang tertimpa musibah (kebangkrutan) sehingga menghabiskan hartanya, maka meminta diperbolehkan baginya hingga memperoleh penopang atau kecukupan hidup lalu ia menahan diri, adapun selain dari tiga kondisi tersebut meminta-minta adalah haram" (H.R. Ahmad)

Terkait hubungan meminta-minta dengan pengamen menurut Kartono (2018) pemerintah harus mengetahui alasan seorang mengambil peran dan identitas sebagai pengamen. Sejalan dengan pemikiran tersebut Rifanto dan Ibrahim (2012) berpendapat bahwa Islam harus berada pada garis terdepan dalam usaha mengayomi keberadaan para masyarakat marjinal. Asmuni (2017) menyarankan bahwa peran ulama dalam pemberdayaan masyarakat marjinal adalah membentuk akhlakul karimah yang baik dibantu oleh pemerintah. Chodiriyanti dan Irawan (2018) berpendapat bahwa kegiatan Program Keluarga Harapan (PKH) merupakan salah satu cara untuk mengayomi dan menyalurkan potensi pengamen agar lebih ekonomis dan menjauhi sifat meminta-minta. Apriyanto (2017) berpendapat bahwa pemerintah harus menyalurkan kontruksi jaminan sosial yang berlapis-lapis yang dimulai dari keluarga 
sampai level masyarakat. Apabila jaminan sosial mampu diselesaikan oleh individu, maka cukup di level individu. Apabila tidak bisa diselesaikan di level individu, maka akan diselesaikan di level keluarga. Apabila tidak selesai di level keluarga, maka akan diselesaikan di level masyarakat. Apabila jaminan sosial tidak selesai di masyarakat, maka kewajiban negara menyelesaikannya. Pernyataan Apriyanto (2017) tersebut didukung oleh pendapat Latif (2014) yang berpendapat bahwa nilai-nilai dasar ekonomi islam terdiri dari; nilai kepemilikan, nilai keadilan, nilai keseimbangan, nilai kebebasan, dan nilai kebersamaan diimplementaskan oleh umat muslim di dunia kerja.

2. Pengamen Tidak Gelandangan

Profesi pengamen tidak hanya dilakukan dengan cara gelandangan atau meminta-minta namun juga ada dengan cara tidak gelandangan sehingga perlakukan hukum Islam terhadap fenomena tersebut akan berbeda-beda pula. Pengamen tidak gelandangan adalah para pengamen yang berusaha untuk menunjukkan profesionalitasnya serta menjauhi segala kategori gelandangan (Putra, 2019). Menurut Kartono (2018) pengamen yang menjauhi unsur meminta-minta memiliki ciri-ciri dari pengamen ini adalah sudah memiliki grup, memiliki izin usaha, tidak berpindah-pindah dalam tempo yang cepat (biasanya 6-12 jam), mempunyai tempat usaha sendiri sesuai dengan izin pemerintah, serta tidak mengharapkan balas kasihan dari orang lain. Pengamen seperti ini sudah berusaha untuk terorganisir dan membentuk nama grup musisi mereka. Pendapatan mereka murni atas upah atas nyanyian mereka bukan karena balas kasihan. Pengamen ini juga memiliki kreativitas tersendiri sehingga memungkinkan adanya persaingan usaha dengan grup lain. Pengamen jenis ini dapat dibagi menjadi dua yaitu (Putra, 2019 dan Masduki \& Widyatama, 2019) :

a. Menjauhi Unsur Meminta-Minta

Pendapatan yang diterima dari pengamen jenis ini adalah tidak meminta-minta kepada pendengarnya akan tetapi melatakkan 3 sampai 4 buah celengan dimana jika pendengar merasa terhibur maka pendengar akan memasukkan uang kedalam celengan tersebut 
sesuai dengan keinginan pendengar. Pengamen ini sudah lepas dari unsur meminta-minta. Pendapatannya didasarkan dari kerelaan pendengarnya. Pengamen jenis ini sudah memiliki grup dan nama grup serta memiliki kreativitas tersendiri sebagai daya jualnya. Contohnya adalah grup angklung yang paling mendominasi di Kota Yogyakarta. Selain itu juga ada musisi-musisi jalanan yang mengamen di café-café Contoh Grup Angklung Cakranada dan Grup Angklung New Banesa Malioboro. Lagu-lagu yang dibawakannya cukup unik mulai dari lagu daerah, lagu pop, dan shalawatan. Pakaian yang dipakai pun juga cukup yaitu dengan memakai pakaian daerah khas ngayogyakorto, pakaian khas keraton, dan pakaian daerah. Selain grup angklung juga ada Musisi Jalanan Yogya seperti grup Musisi Jogja Project. Grup ini sudah milenial dan kekinian (Putra, 2019).

Pengamen yang menjalankan profesinya dengan tidak gelandangan namun melalui kreativitas dan usaha untuk menghibur serta cara memperoileh pendapatannya bukan melalui memintaminta apalagi dengan berharap balas kasihan dari orang lain maka hukumnya mubah bahkan dianjurkan jika terdapat manfaat yang lain. Contohnya adalah grup angklung yogya selain untuk memenuhi kebutuhannya mereka juga turut melestarikan budaya. Selain itu juga merupakan salah satu faktor daya tarik sendiri bagi wisatawan baik lokal maupun asing untuk datang ke Yogyakarta sehingga akan memberikan manfaat kepada orang lain (Rafi, Hamzah, dan Rafif 2018).

b. Terdapat Unsur Meminta-Minta

Pengamen jenis ini berusaha untuk menonjolkan kreativitasnya namun berusaha untuk menjauhi sifat meminta-minta atau gelandangan (Putra, 2019). Meskipun hukum meminta-minta adalah haram tetapi jika terdapat kondisi tertentu yang dapat menghacam tujuan muamalah maka hukum profesi pengamen dengan cara meminta-minta dapat berubah. Menurut Fahlepy (2018) terdapat kondisi dimana hukum meminta-minta menjadi mubah yaitu jika kondisi seseorang mempunyai tanggungan sampai dia 
mampu untuk menyelesaikan tanggungannya dan jika sudah lepas tanggungan tersebut maka harus berhenti meminta-minta.

Tujuan adanya maqashid syariah adalah untuk mewujudkan kebaikan dan kesejahteraan (mashlahah) umat manusia di dunia dan akhirat. Untuk mencapai tujuan ini ada lima unsur pokok yang harus dipelihara yang dinamakan mashlahuh khamsah yang terdiri dari agama, jiwa akal, keturunan, dan harta (Nurhayati dan Wasilah, 2015). Adapun jika terdapat kondisi atau situasi yang dapat mengancam kelima unsur pokok ini maka tindakan apapun diperbolehkan sampai datang kesempatan untuk keluar dari ancaman tersebut. Artinya dalam Islam hukum menjadi seorang pengamen adalah mubah atau boleh jika berada dalam keadaan terpaksa yang dapat mengancam mahslahuh khamsah. Allah SWT berfirman :

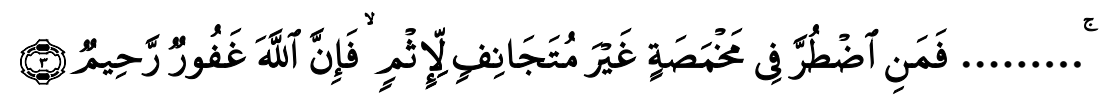

“...........Maka barang siapa terpaksa karena kelaparan tanpa sengaja berbuat dosa, Sesungguhnya Allah Maha Pengampun lagi Maha Penyayang” (Q.S. Al Maidah ayat 3)

Selain untuk memenuhi kebutuhan yang sangat mendesak profesi pengamen adakalanya dilakukan dengan niat untuk kepentingan sosial (Masduki dan Widytama, 2019). Contohnya adalah organisasi kampus yang mengamen untuk mencari dana kegiatannya baik berpindah tempat ataupun berada disuatu titik tergantung izin dari pihak yang berweweng (seperti kepolisian atau pihak pendistrisian wisata). Profesi pengamen seperti ini berkaitan dengan adanya semangat tolong menolong atau didalam Islam disebut dengan ta'awun dimana umat Islam dianjurkan untuk saling menolong dalam kebaikan dan tidak boleh saling tolong menolong dalam berbuat dosa. Profesi pengamen dengan upaya untuk bakti sosial merupakan perkara kebajikan sehingga hukum pengamen untuk kepentingan sosial adalah sunnah. Perilaku seperti ini mencerminkan sikap Ta'awun yaitu suatu sikap saling tolong menolong dalam kabijkan antar sesama manusia (Masduki dan 
Widytama, 2019). Hal ini dianjurkan di dalam Islam karena firman Allah SWT dalam Q.S. Al-Maidah ayat 2 :

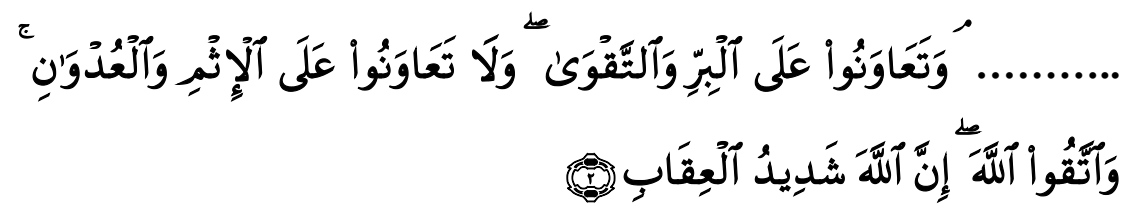

....... dan tolong-menolonglah kamu dalam (mengerjakan) kebajikan dan takwa, dan jangan tolong-menolong dalam berbuat dosa dan pelanggaran. dan bertakwalah kamu kepada Allah, Sesungguhnya Allah Amat berat siksa-Nya.(Q.S. Al-Maidah : 2)

Dari ayat diatas terlihat bahwa Islam menganjurkan untuk saling tolong menolong. Pengamen yang menjalankan profesinya dengan tidak gelandangan tetapi meminta-minta dengan tujuan untuk kepentingan sosial merupakan salah satu cara dalam rangka mewujudkan saling tolong menolong di dalam Islam. Profesi ini dilakukan untuk mengajak para relawan untuk bersedakah dan sedekah tersebut digunakan dalam rangka kegiatan bakti sosial. Hukum profesi mengamen dengan cara meminta-minta untuk kepentingan sosial hukumnya adalah sunnah karena transaksi yang terjadi disini merupakan transaksi sosial dimana mengharapkan sumbangan atau sedekah bagi pendengarnya. Hasilnya disumbangan dan bermanfaat untuk orang lain.

\section{KESIMPULAN}

Adapun kesimpulan dari hasil penelitian ini 1) pengamen yang menjalankan profesinya dengan cara gelandangan dan mengemis maka hukumnya haram karena tidak mengikuti aturan yang ditetapkan pemerintah meskipun hukum meminta-minta dalam Islam kategori jarimah ta'zir dan menjadi mubah jika dengan alasan terpaksa atau terdesak, 2) pengamen yang menjalankan profesinya dengan cara tidak gelandangan dan menjauhi prilaku meminta-minta maka hukumnya mubah dan menjadi sunnah jika diniatkan untuk ibadah dalam rangka memberi manfaat kepada orang lain, 3) pengamen yang menjalankan profesinya dengan cara tidak gelandangan namun dengan jalan meminta-minta untuk kebutuhan sendiri maka 
hukumnya makruh dan jika digunakan untuk kepentingan sosial maka hukumnya sunnah karena dengan niat membantu orang lain dengan syarat tidak dilakukan secara terus menerus.

\section{E. DAFTAR PUSTAKA}

\section{BUKU}

Al-Misri, Mahmud. (2008), Sirah Shahabiyah Jilid 1. Jakarta: Al-I'tshom Cahaya Utama.

Ath-Thyayyar, A, B, M. Al Muthlaq. A, B, M. dan Al Musa, M, B, I. (2017). Al Fiqhul-Muyassar Qismul-Mu'amalat, Mausu'ah Fiqhiyyah Haditsah Tatanawalu Ahkamal-Fiqhil-Islami Bi Uslub Wadhih Lil-Mukhtashshin Wa Ghairihim. (Terjemahan oleh Miftahul Khairi). Yogyakarta : Maktabah Al Hanif.

Departemen Agama, R. I. (2009). Al-Quran Al-Karim. Bandung: PT. Sygma Examedia Arkanleema.

Djazuli. (2006). Kaidah-Kaidah Fiqih: Kaidah-Kaidah Hukum Islam dalam Menyelesaikan Masalah-Masalah yang Praktis, Ed.1, cet. 3, Jakarta: Kencana

Edi Suharto, 2011, Kebijakan Sosial Sebagai Kebijakan Publik, Alfabeta, Bandung

Ghozaly. A. R, Ihsan.G, dan Shidiq, S. (2012). Fiqh Muamalah. Jakarta : Kencana.

Iska. S 2012. Sistem Perbankan Syariah di Indonesia.Yogyakarta: Fajar Media Press

Iska. S dan Rizal. (2005). Lembaga Keuangan Syariah. Batusangkar : Batusangkar Press

Nurhayati, S. dan Wasilah. (2015). Akuntansi Syariah di Indonesia. Jakarta : Salemba Empat

Pusat Bahasa Departemen Pendidikan Nasional. (2008). Kamus Besar Bahasa Indonesia.. Jakarta: Balai Pustaka.

Sayyid Sabiq. (1983). Fiqh Sunnah. Jilid III Cetakan IV. Beirut : Dar al-Fikr.

Sugiyono. (2014), Metode Penelitian Kuantitatif Kualitatif dan $R \& D$, Bandung: Alfabeta.

\section{JURNAL}

Aprianto, N. E. K. (2017). Kontruksi Sistem Jaminan Sosial dalam Perspektif Ekonomi Islam. Economica: Jurnal Ekonomi Islam, 8(2), 237-262.

Asmuni, A. (2017). Peran Ulama dalam Pemberdayaan Masyarakat Marjinal. Empower, 2(1).

Chodariyanti, L., \& Irawan, M. R. N. (2018). Implementasi Masyarakat Kampung Pengamen Trisnomulyo Melalui Program Keluarga Harapan (Studi Kasus Masyarakat Kampung Pengamen Trisnomulyo Kelurahan 
Sidoharjo Kecamatan Lamongan). JURNAL MANAJEMEN, 3(3), 747822.

Fahlepy, R. (2018). Analisis Hukum Islam Terhadap Jarimah Minta-Minta Yang Dilakukan Oleh Anak. Jurnal de jure, 10(2).

Fulzi, N. (2016). Alam Dan Adat Sebagai Sumber Estetika Lokal Kesenian Talempong Lagu Dendang. Ekspresi Seni, 18(1), 164-179.

Ipandang, I. (2014). Hak-Hak Anak Jalanan Di Kota Makassar: Perspektif Hukum Islam dan Hukum Positif. STAIN Kendari. Jurnal Diskursus Islam Volume 2 Nomor 2.

Kartono, D. T. (2018). Orkhestra Jalanan Di Kota Tentang Menjadi Pengamen, Organisasi Sosial Dan Eksistensi Dalam Kehidupan Kota. Dialektika Masyarakat: Jurnal Sosiologi, 2(1), 59-72.

Latif, A. (2014). Nilai-Nilai Dasar Dalam Membangun Ekonomi Islam. DIKTUM: Jurnal Syariah dan Hukum, 12(2), 153-169.

Masduki, A., \& Widyatama, R. (2019). Efektifitas Strategi Komunikasi Politik Elit Muhammadiyah DIY dalam Pemenangan Pemilu DPD-RI Tahun 2014. Communicare, 5(1), 1-18.

Masunah, J. (2015). Pemuliaan Angklung melalui Model Desa Binaan Berbasis Wisata Seni dan Budaya. Panggung, 22(1).

Munawaroh, R. (2009). Tinjauan hukum Islam tentang pelaksanaan pengupahan karyawan di Perusahaan Umum Damri Semarang (Doctoral dissertation, IAIN Walisongo).

Nugroho, A. S., Sularto, R. B., \& Wisaksono, B. (2017). Tinjauan Kriminologis Tindak Premanisme Oleh Pengamen Di Simpang Lima Kota Semarang. Diponegoro Law Journal, 6(1), 1-19.

Pratama, R. G. (2017). Perlindungan Hukum Terhadap Kesejahteraan Anak Jalanan Di Kabupaten Subang. LAW Enforcement: JURNAL ILMU HUKUM, 8(1), 61-73.

Putra, A. P., \& Susetyo, B. (2012). Bentuk Pertunjukan Kesenian Angklung Carang Wulung. Jurnal Seni Musik, 1(1).

Putra, M. L. (2019). Implementasi Peraturan Daerah Nomor 1 Tahun 2014 Tentang Penanganan Gelandangan dan Pengemis di Daerah Istimewa Yogyakarta. LAW Enforcement: JURNAL ILMU HUKUM, 8(1), 61-73.

Rafi, M., Hamzah, S., \& Rafif, A. A. (2018). Makna Sa 'il Dalam Al-Qur'an: Tujuan Implisit Pengentasan Pengemis Dalam Ayat-Ayat Sa 'Il dan Aktualisasinya. Jurnal Studi Ilmu-ilmu Al-Qur'an dan Hadis, 18(1), 1732.

Ridho, M. (2016). Pemberdayaan Anak Jalanan Dalam Pandangan Islam. NUANSA: Jurnal Penelitian Ilmu Sosial dan Keagamaan Islam, 13(2), 251-266. 
Ridwan, R. B., \& Ibrahim, I. A. (2012). Ahkam al-Laqit: Konsep Islam dalam Menangani Anak Jalanan di Indonesia. Tsaqafah, 8(2), 311-330.

Saraswati, D. (2018). Motivasi Berprestasi pada Pemusik Angklung. Yogyakarta: Universitas Ahmad Dahlan.

Syakur, A. (2015). Standar Pengupahan dalam Ekonomi Islam (Studi Kritis atas Pemikiran Hizbut Tahrir). UNIVERSUM, 9(1)

Nugroho, A. S., Sularto, R. B., \& Wisaksono, B. (2017). Tinjauan Kriminologis Tindak Premanisme Oleh Pengamen Di Simpang Lima Kota Semarang. Diponegoro Law Journal, 6(1), 1-19.

Tarmudzi, M. I. (2015). Perlindungan Hukum Terhadap Pekerja Anak Di Sektor Informal. Al-Jinayah: Jurnal Hukum Pidana Islam, 1(2), 383-398.

Uli, P. B. (2012). Identifikasi Lagu Pengamen Jalanan Di Kota Medan (Doctoral dissertation, UNIMED).

Walian, A. W. (2012). Konsepsi Islam Tentang Kerja Rekonstruksi Terhadap Pemahaman Kerja Seorang Muslim. An Nisa'a, 7(1), 65-80.

Wardi, M. C. (2014). Pencarian Dana Masjid di Jalan Raya Dalam Perspektif Hukum Islam. AL-IHKAM: Jurnal Hukum \& Pranata Sosial, 7(2), 331357

Yendika, F. O. (2011). Apresiasi Mahasiswa Seni Musik Terhadap Lagu-lagu Pengamen Jalanan Di Kota Semarang (Doctoral dissertation, Universitas Negeri Semarang).

Yenti, Z., Huda, S., \& Piadi, A. (2008). Anak Jalanan di Simpang Lampu Merah Telanaipura Kota Jambi (Analisis Terhadap Dampak Eksploitasi Anak). Kontekstualita: Jurnal Penelitian Sosial Keagamaan, 23(2).

\section{UNDANG-UNDANG DAN PERATURAN DAERAH}

Peraturan Daerah Kota Makasar Nomor 2 Tahun 2008 Tentang Pembinaan Anak Jalanan, Gelandangan, Pengemis, dan Pengamen

Peraturan Daerah Provinsi Daerah Istimewa Yogyakarta Nomor 1 Tahun 2014 tantang Penanganan Gelandangan dan Pengemis

Undang-Undang Nomor 31 Tahun 1980 tentang Penanggulangan Gelandangan dan Pengemis 